\title{
Peningkatan Manajemen Usaha Dan Diversifikasi Produk Usaha Rumahan Jajanan Tradisional Desa Bintoro, Kabupaten Demak
}

\author{
Ratna Wijayanti ${ }^{1}$, Suratman $^{2}$, Ika Fitriana ${ }^{3}$ \\ Program Studi $\mathrm{S}_{1}$ Manajemen, Fakultas Ekonomi, Universitas Semarang ${ }^{1,2}$ \\ Program Studi $\mathrm{S}_{1}$ Teknologi Hasil Pertanian, Fakultas Teknologi Pertanian, Universitas \\ Semarang ${ }^{3}$ \\ ru7nawijayanti@usm.ac.id
}

\begin{abstract}
The focus of this PKM are efforts to improve business management and home industry production quality in Demak Regency. Partners are home industry business actors with various market snacks products. Based on the situation analysis, partners have problems in production aspects and business management. Problems in production are limited tools, partners use manually production. The problem in marketing is the limited marketing reach, the product is only sold in one traditional market. The problem in financial aspect are that partners do not have financial books and records so that profits or losses cannot be detected properly. The solutions offered for problems in the production aspect are Machine facilitation and workshops for Mixing Dough and Making Frozen Food Products. Solutions for marketing aspects, namely training and workshops on making product variations and packaging. Solutions for financial aspects include training in simple bookkeeping and business financial management. All of the target solutions offered have been fulfilled by the PKM team to partners. The benefits that partners get from this community service program include: (1) Increased turnover, (2) Improved Machine Use Skills, (3) Improved Partner Understanding and Skills in Doing Simple Bookkeeping and separating family and business finances and (4) Expanding Marketing Reach
\end{abstract}

Keywords: Marketing, Finance, Production, Business Management

\begin{abstract}
Abstrak
Fokus pelaksanaan PKM ini adalah upaya peningkatan manajemen usaha dan kualitas produksi industri rumahan ibu rumah tangga di Kabupaten Demak. Mitra merupakan pelaku usaha industri rumahan dengan produk aneka jajanan pasar. Berdasarkan analisis situasi, mitra memiliki permasalahan dalam aspek produksi dan manajemen usaha. Permasalahan dalam aspek produksi yaitu keterbatasan alat dalam berproduksi, mitra menggunakan tangan atau secara manual. Permasalahan dalam aspek pemasaran adalah jangkauan pemasaran yang terbatas, produk hanya dijual di satu pasar tradisional. Permasalahan aspek keuangan yaitu mitra tidak
\end{abstract}


memiliki pembukuan dan pencatatan keuangan sehingga menyebabkan keuntungan atau kerugian tidak dapat terdeteksi dengan baik. Solusi yang ditawarkan untuk permasalahan pada aspek produksi yaitu Fasilitasi Mesin serta workshop Pengaduk Adonan dan Pembuat Produk Frozen Food. Solusi aspek pemasaran yaitu Pelatihan dan Workshop pembuatan variasi produk serta Packaging,. Solusi aspek keuangan meliputi Pelatihan pembukuan sederhana dan pengelolaan keuangan usaha. Keseluruhan target solusi yang ditawarkan telah dipenuhi semua oleh tim PKM kepada mitra. Manfaat yang diperoleh mitra dari program pengabdian kepada masyarakat ini meliputi: (1) Peningkatan omzet, (2) Peningkatan Keterampilan Penggunaan Mesin, (3) Peningkatan Pemahaman dan Keterampilan Mitra dalam Melakukan Pembukuan Sederhana dan memisahkan keuangan keluarga dan bisnis dan (4) Perluasan Jangkauan Pemasaran.

Kata Kunci : Pemasaran, Keuangan, Produksi, Manajemen Usaha

\section{PENDAHULUAN}

Di Kabupaten Demak, UMKM merupakan salah satu sektor unggulan yang diprioritaskan pengembangannya, di samping 3 sektor lain yaitu pertanian, kelautan perikanan dan pariwisata. UMKM masih diyakini sebagai usaha yang tahan krisis dan mampu menggerakan roda perekonomian. Secara umum bidang usaha UMKM dibagi menjadi 2 kelompok besar yaitu pertanian dan non pertanian. UMKM non pertanian memiliki jumlah yang lebih banyak dibandingkan kelompok pertanian. Tiga bidang usaha UMKM non pertanian yang jumlah pelaku usahanya menduduki peringkat teratas adalah 1) perdagangan besar dan eceran, 2) penyediaan akomodasi dan penyediaan makan minum, 3) industry pengolahan. Mayoritas industri pengolahan bergerak dibidang makanan dan minuman. Industri pengolahan banyak disebut industri rumahan, karena tempat usaha atau produksi menjadi satu dengan rumah para pengusaha. Industri rumahan yang tersebar di seluruh Kecamatan di Kabupaten Demak adalah industri makanan atau jajanan.

Kecamatan Demak merupakan salah satu kecamatan di Kabupaten Demak yang memiliki jumlah industri rumahan yang cukup besar. Tidak sedikit perempuan di Kabupaten Demak menggeluti kegiatan industri rumahan untuk membantu ekonomi keluarga. Bahkan dengan langkah tersebut, ibu-ibu rumah tangga menjadi tulang punggung keluarga selama berpuluh-puluh tahun. Seperti hal nya industri rumahan ibu Sukesi. Ibu Sukesi telah menjalankan usaha berpuluh-puluh tahun lamanya guna menompang perekonomian keluarga. Industry rumahan yang digeluti tersebut adalah industry makanan kecil dan aneka kue (jajanan pasar). Usaha tersebut berlokasi di Kampung Tanubayan Rt.06/09 Bintoro Demak.

Gambaran usaha ibu Sukesi sebagai mitra PKM adalah sebuah industry kecil rumahan yang kegiatan produksinya adalah membuat jajan pasar seperti pisang molen, kue dadar gulung, bakpao, wingko babat dan donat, selain jajan tradisional ibu sukesi juga membuat aneka snack 
seperti tahu bakso, risoles, dll. Ibu Sukesi memulai usaha sejak tahun 1984 dan masih bertahan sampai sekarang. Usaha ini memiliki 2 orang karyawan. Setiap hari usaha ini membutuhkan 20 $\mathrm{kg}$ adonan tepung untuk membuat produk jajanan pasar. Produk jajanan pasar Ibu Sukesi hanya dipasarkan di satu pasar tradisional di Kecamatan Demak yaitu Pasar Bintoro, dengan omzet rata-rata perhari sebesar Rp. 800.000,
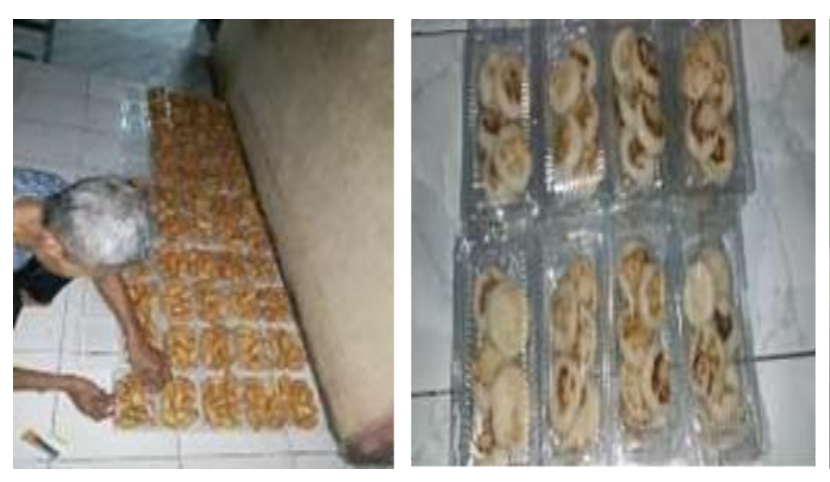

Gambar 1.

Produk Mitra (Kemasan Produk Terlihat Tidak Menarik, dan Tidak Ada Informasi atau Keterangan Produk dalam Kemasan)
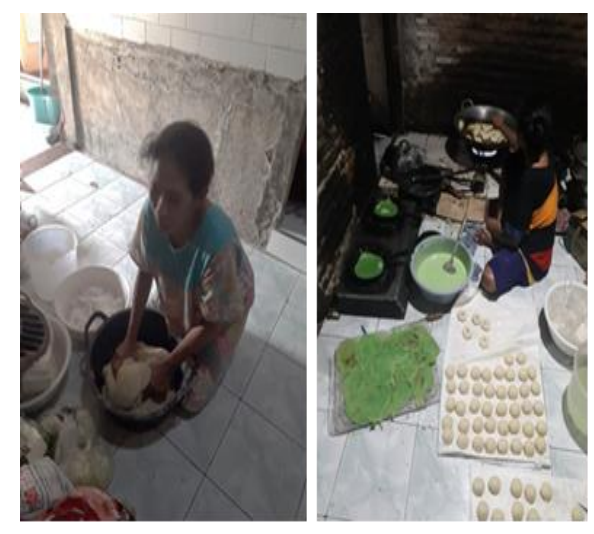

Gambar 2.

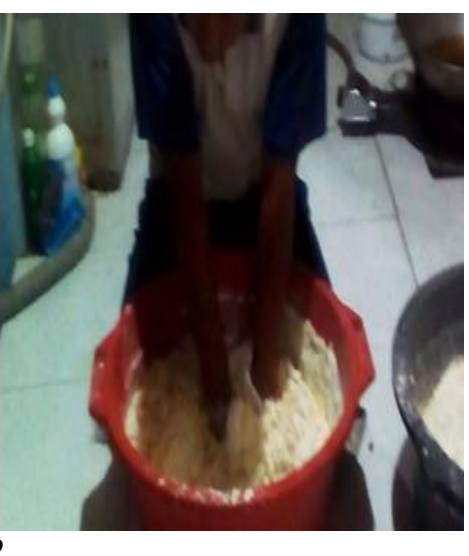

Proses Produksi Mitra (Mitra secara Manual dalam Membuat Adonan Roti)

Usaha ini meski telah berpuluh-puluh tahun lamanya tidak pernah mendapatkan bantuan dari Pemerintah. Setelah melakukan prasurvei terhadap kondisi mitra, Tim PKM memetakan beberapa permasalahan-permasalahan yang dihadapi mitra dalam menjalankan usahanya. Mitra memiliki permasalahan yang sama baik dari aspek produksi, keuangan dan pemasaran.

Permasalahan aspek produksi yaitu mitra tidak memiliki mesin atau peralatan produksi yang memadai. Selama ini mitra menggunakan cara manual yaitu mengaduk dengan tangan dalam membuat adonan jajan pasar. Dalam mengaduk adonan dengan berat hampir $25 \mathrm{~kg}$ setiap produksi, mitra menggunakan tenaga manusia. Hal ini menyebabkan tidak efektifnya waktu yang digunakan mitra sehingga mitra menjadi kurang produktif dan hanya menghasilkan produkproduk yang terbatas baik dari sisi kuantitas maupun kualitas, karena tenaga mitra sudah terkuras untuk membuat adonan. Selain itu proses manual yang dijalani dalam membuat adonan berdampak pada kesehatan mitra. Sisa tepung yang menempel pada tangan mitra menyebabkan 
tumbuhnya jamur yang merusak kuku tangan mitra. Adonan yang diaduk secara manual dengan tangan juga jauh dari higienis.

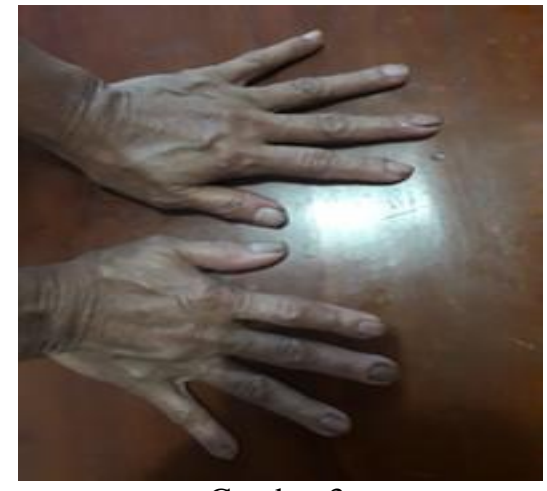

Gambar 3.

Kuku Tangan Mitra yang Mengalami Kerusakan

Selain itu dampak pandemic Covid-19 juga sangat dirasakan oleh usaha ini, omzet yang semula rata-rata Rp. 800.000 per hari menjadi turun tajam hanya sekitar Rp. 200.000 per hari, bahkan kurang dari itu. Produk-produk jajanan tidak diminati dikala pandemic, untuk itu usaha ini memerlukan strategi di bidang produksi untuk menarik minat konsumen kembali. Usaha ini perlu melakukan diversifikasi produk agar tetap bertahan di kala krisis. Diversifikasi ini bertujuan untuk memperluas usaha mitra. Diversifikasi produk yang dikembangkan tidak jauh dari usaha inti, yaitu mitra dapat melakukan diversifikasi konsentris dengan mengembangkan produknya. Mitra harus mampu menyiapkan amunisi lain untuk tetap bertahan di kala pandemic, jika produk jajanan kurang diminati maka mitra dapat memproduksi olahan makanan lain yang disesuaikan dengan situasi pandemic. Mitra dapat mengembangkan produknya menjadi produk frozen food, dan menambah variasi produk yang disesuaikan dengan minat dan kebutuhan pasar saat ini. Frozen food dapat menjadi inovasi usaha bagi pelaku UMKM yang relevan untuk dilakukan di tengah situasi pandemic. Produk-produk frozen food yang dapat dikembangkan oleh mitra seperti olahan bakso, sosis, nugget maupun snack frozen. Frozen food menjadi pilihan masyarakat di kala pandemic, produk makanan kategori ini menjadi alternatif pilihan bagi masyarakat untuk memenuhi kebutuhan pangan mereka. Selain itu, diversifikasi produk yaitu pengembangan produk menjadi frozen food potensial bagi mitra dalam pengembangan usahanya ke depan pasca pandemic. Hal ini merupakan peluang usaha bagi mitra untuk melakukan diversifikasi sebagai bagian dari adaptasi usaha untuk mengimbangi perubahan yang ada di masyarakat pada masa pandemi.

Permasalahan aspek pemasaran yaitu jangkauan pemasaran dari mitra masih sangat terbatas yaitu produk hanya di pasarkan di satu pasar tradisional di kecamatan Demak, mengingat di Kecamatan Demak sendiri terdapat 3 pasar tradisional yaitu Pasar Bintoro, Pasar Buyaran dan Pasar Sedo. Mitra tidak mampu melayani kedua potensi pasar yang lain, hal tersebut dikarenakan kuantitas produk yang dihasilkan mitra terbatas serta kurangnya variasi produk yang dihasilkan mitra. Mitra kurang mampu dalam mengembangkan variasi produk jajan pasar yang mengikuti trend dan minat pasar. Selain itu kemasan produk mitra kurang menarik dan tidak memiliki ciri khas sehingga produk mitra terkesan sama dengan penjual-penjual jajanan pasar lainnya. Kurangnya pengetahuan manajemen usaha dan startegi pemasaran produk menjadi sebab usaha mitra sulit berkembang (Ebert \& Griffin, 2007). Seperti diketahui manajemen pemasaran adalah kegiatan menganalisis, merencanakan, melaksanakan, dan mengendalikan program-program yang disusun dalam pembentukan, pembangunan, dan 
pemeliharaan keuntungan dari pertukaran/transaksi melalui pasar sasaran untuk mencapai tujuan dalam jangka panjang (Assauri 2013).

Masalah klasik yang dihadapi oleh UMKM dari segi keuangan yaitu dalam pengelolaan administrasi keuangan. Mitra tidak pernah melakukan administrasi keuangan atau pembukuan keuangan sederhana. Antara keuangan pribadi/keluarga tercampur menjadi satu dengan keuangan usaha. Hal tersebut menyebabkan keuntungan usaha tidak dapat dideteksi secara mudah. Padahal pencatatan adminitrasi keuangan menjadi bagian penting dalam menjalankan industri kecil. Sebab dengan administrasi atau pencatatan keuangan mitra akan tahu berapa besar biaya produksi yang dikeluarkan dan berapa besar keuntungan riil yang didapat setiap bulan. Selain itu untuk menjalankan diversifikasi atau pengembangan produknya, mitra membutuhkan suatu pelatihan dalam menghitung biaya produksi produk diversifikasi sehingga harga jual dapat ditentukan secara tepat.

Meskipun memiliki beberapa kendala, usaha ini tetap memiliki potensi untuk dikembangkan. Dengan keterbatasan yang ada, usaha ini mampu bertahan berpuluh-puluh tahun lamanya. Mitra telah memiliki keahlian dalam membuat makanan olahan sehingga mitra memerlukan tamabahan ilmu untuk mengembangkan keahliannya untuk menjadi lebih professional. Selain itu produk jajan pasar eksistensinya akan bertahan lama karena menjadi salah satu ciri khas makanan tradisional, dan juga produk diversifikasinya menjadi produk yang dibutuhkan masyarakat setiap hari.

Potensi pasar mitra masih dapat diperluas yaitu dengan masuk di pasar-pasar tradisional lain di Kecamatan Demak, serta perluasan usahanya dengan produk-produk diversifikasi yang dihasilkan. Usaha ini pun dapat diteruskan oleh generasi berikutnya sehingga sejalan dengan tujuan Pemerintah yaitu menciptakan wirausaha-wirausaha baru yang turun temurun dengan harapan usaha yang semakin berkembang.

Pemberdayaan UMKM khususnya industri rumahan ibu-ibu rumah tangga sangat perlu dilakukan karena sebagian besar usaha mereka menopang ekonomi keluarga. PKM ini bertujuan untuk meningkatkan kemampuan bisnis mitra, baik dari segi produksi, keuangan dan pemasaran. Terutama bagi ibu rumah tangga dalam mengembangkan bisnis berbasis rumah tangga. Kegiatan pemberdayaan masyarakat yang baik pada umumnya mensyaratkan adanya proses pendampingan (Nurita, 2016). Fungsi pendampingan ini sejalan dengan PKM yang akan dilaksanakan yaitu dengan memfasilitasi, memotivasi, serta mengawal agar seluruh kegiatan dapat sesuai dengan maksud dan tujuan yang dirumuskan bersama antara Tim PKM dan Mitra.

\section{METODE}

Metode pelaksanaan yang digunakan dalam program kemitraan masyarakat ini adalah partisipatori. Participatory training yaitu mitra dilibatkan penuh dan ditekankan partisipasi aktifnya dalam seluruh kegiatan PKM, mulai dari perencanaan sampai dengan evaluasi. Sejalan dengan prioritas permasalahan mitra yang disepakati dan ditangani bersama, berikut adalah tahapan pelaksanaan kegiatan:

1. Observasi: meliputi kegiatan Pra Survei Lapangan, Persiapan Alat dan Bahan Pelatihan serta Persiapan Tempat Pelatihan dan Workshop.

2. Fasilitasi Mesin dan Workshop penggunaan mesin.

3. Penyuluhan Pentingnya Higeinitas dalam Produksi.

4. Pelatihan Pemasaran Online dan Workshop Pengemasan Produk bagi Usaha Kecil.

5. Pelatihan pembukuan sederhana dan pengelolaan keuangan untuk UMKM.

6. Pelatihan Penentuan Harga Jual Produk. 
7. Evaluasi Kinerja.

Metode pelaksanaan di atas diselaraskan dengan permasalahan mitra dan tujuan dari pelaksanan PKM ini.

Tabel 1

Permasalahan, Tujuan dan Metode Pelaksanaan

\begin{tabular}{|c|c|c|}
\hline Permasalahan & Tujuan & Metode Pelaksanaan \\
\hline $\begin{array}{l}\text { Aspek Produksi: } \\
\text { Keterbatasan alat dalam berproduksi yaitu mitra } \\
\text { menggunakan tangan atau secara manual } \\
\text { mengaduk adonan kue yang beratnya hampir } 25 \\
\text { kg. Keterbatasan tersebut menyebabkan produk } \\
\text { yang dihasilkan mitra terbatas baik dari sisi } \\
\text { kuantitas maupun kualitas. Selain itu, hal } \\
\text { tersebut berimbas pada kesehatan mitra, sisa-sisa } \\
\text { tepung yang tertinggal di tangan memicu } \\
\text { pertumbuhan jamur pada kuku tangan mitra. } \\
\text { Sehingga kuku tangan mitra menjadi rusak dan } \\
\text { produk tidak higienis } \\
\text { Penurunan omzet mitra di masa pandemic covid } \\
\text { 19, memberikan peluang bagi mitra untuk } \\
\text { melakukan diversifikasi produk. Produk-produk } \\
\text { yang dapat dikembangakan sesuai keahlian mitra } \\
\text { adalah olahan bakso, nugget, sosis dan aneka } \\
\text { snack. }\end{array}$ & $\begin{array}{l}\text { Peningkatan } \\
\text { Kemampuan } \\
\text { Bisnis Mitra dari } \\
\text { segi Produksi }\end{array}$ & $\begin{array}{ll}\checkmark & \text { Fasilitasi Mesin } \\
& \text { Produksi (Mesin } \\
& \text { Pengaduk Adonan) } \\
\checkmark & \text { Fasilitasi Mesin } \\
& \text { Pembuat Produk } \\
& \text { Frozen Food (Vacum } \\
& \text { Sealer, Meat Grinder, } \\
& \text { Meat Mixer, Mesin } \\
& \text { Coding, Frezer) } \\
\checkmark & \text { Workshop } \\
\text { penggunaan fasilitas } \\
\text { mesin-mesin } \\
\checkmark & \text { Penyuluhan } \\
\text { Pentingnya Higienitas } \\
\text { dalam Produksi } \\
\text { Makanan }\end{array}$ \\
\hline $\begin{array}{l}\text { Aspek Pemasaran: } \\
\text { Jangkauan pemasaran mitra sangat terbatas. } \\
\text { Kurangnya variasi produk dari mitra, produk } \\
\text { mitra mengalami kejenuhan pasar. Sehingga } \\
\text { untuk memperluas pemasaran, mitra perlu } \\
\text { melakukan perluasan produk dengan } \\
\text { diversifikasi konsentris. }\end{array}$ & $\begin{array}{l}\text { Peningkatan } \\
\text { Kemampuan } \\
\text { Bisnis Mitra dari } \\
\text { segi Pemasaran }\end{array}$ & $\begin{array}{l}\checkmark \text { Pelatihan dan } \\
\text { Workshop pembuatan } \\
\text { variasi produk serta } \\
\text { Packaging yang } \\
\text { menarik untuk produk } \\
\text { UMKM }\end{array}$ \\
\hline $\begin{array}{l}\text { Aspek Keuangan: } \\
\text { Mitra tidak memiliki pembukuan dan pencatatan } \\
\text { keuangan. Keuangan keluarga dan bisnis } \\
\text { bercampur jadi satu } \\
\text { Mitra belum mampu menentukan harga pokok } \\
\text { produksi produk diversifikasinya sebagai dasar } \\
\text { penentuan harga jual. }\end{array}$ & $\begin{array}{l}\text { Peningkatan } \\
\text { Kemampuan } \\
\text { Bisnis Mitra dari } \\
\text { segi Keuangan }\end{array}$ & $\begin{array}{ll}\checkmark & \text { Pelatihan pembukuan } \\
& \text { sederhana dan } \\
& \text { pengelolaan keuangan } \\
& \text { untuk UMKM } \\
\checkmark & \text { Pelatihan penentuan } \\
& \text { harga jual produk }\end{array}$ \\
\hline
\end{tabular}

\section{HASIL DAN PEMBAHASAN}

\section{Hasil}

Kegiatan program pengabdian kepada masyarakat dimulai dengan kegiatan Pra Survei Lapangan, Persiapan Alat dan Bahan Pelatihan serta Persiapan Tempat Pelatihan dan Workshop. Dilanjutkan dengan beberapa kegiatan antara lain: 
1. Fasilitasi Mesin dan Workshop penggunaan mesin. Meliputi kegiatan penyerahan mesin kepada mitra untuk selanjutnya dilakukan workshop penggunaan mesin oleh mitra. Tujuan dari kegiatan ini adalah untuk meningkatkan keterampilan mitra dalam menggunakan alat produksi yang tepat guna sehingga pada nantinya mampu meningkatkan kuantitas, kualitas serta omzet penjualan mitra
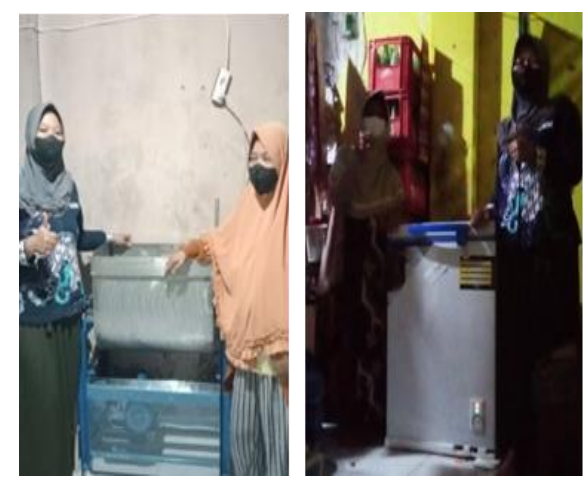

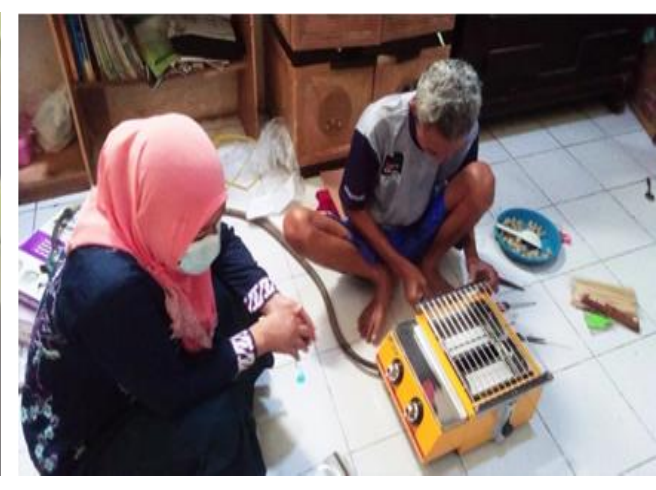

Gambar 4.

Fasilitasi Mesin
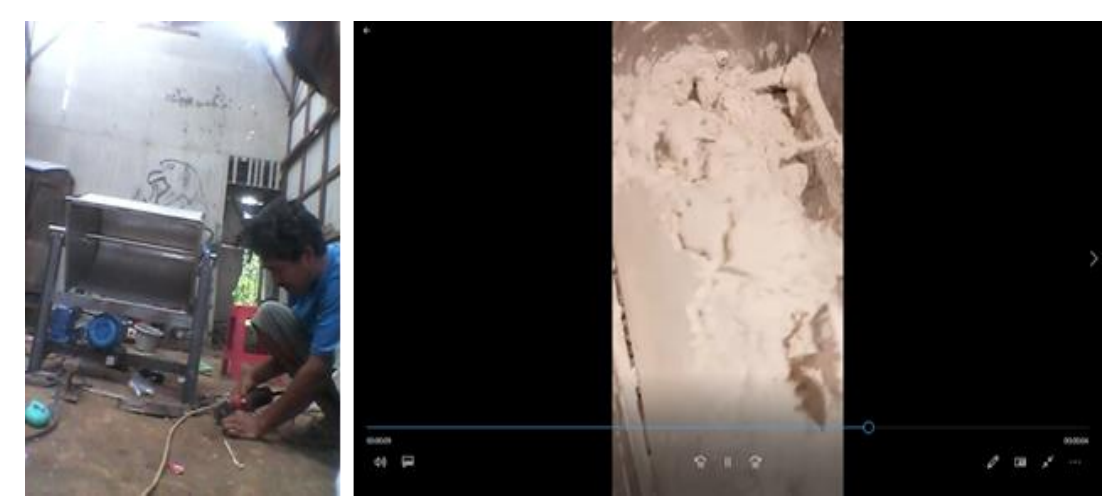

Gambar 5.

Workshop Penggunaan Mesin

2. Penyuluhan Pentingnya Higeinitas dalam Produksi. Tujuan dari pelatihan ini adalah peningkatan pemahaman dan keterampilan Mitra tentang cara berproduksi pangan yang baik. Melalui cara produksi pangan yang baik, industri pangan dapat menghasilkan pangan yang berkualitas, layak dikonsumsi, dan aman bagi kesehatan (Boko, 2006). Produk higienis dimulai dengan memperhatikan kebersihan diri dan perilaku produsen itu sendiri, peralatan kerja, karyawan, serta kebersihan lingkungan. Materi pelatihan yang akan disampaikan meliputi 1) Cara produksi pangan yang baik, 2) Sanitasi Higiene di Bidang Pangan, 3) Sanitasi dalam pengelolaan (Personal, Inventarisasi, Fasilitas, Peralatan). 


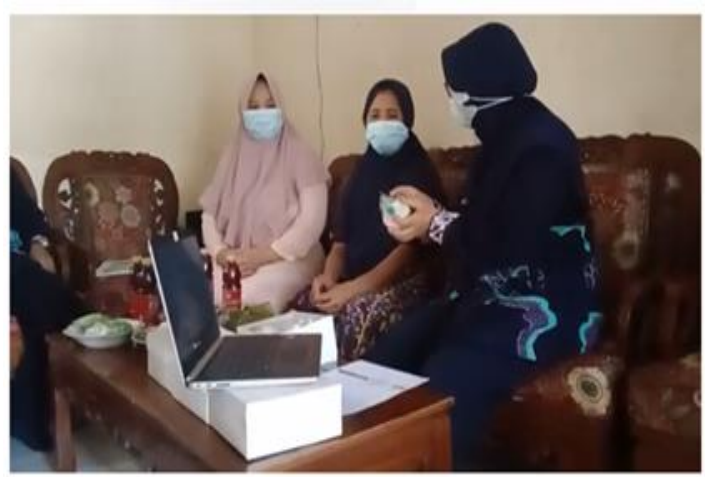

Gambar 6.

Penyuluhan Pentingnya Higeinitas dalam Produksi

3. Pelatihan Pemasaran Online dan Workshop Pengemasan Produk bagi Usaha Kecil. Pelatihan ini bertujuan untuk meningkatkan pemahaman dan keterampilan mitra dalam menerapkan strategi pemasaran. Materi yang akan disampaikan dalam pelatihan ini yaitu manajemen pemasaran dan strategi pemasaran marketing mix (4P dan STP). Selain pelatihan pemasaran, tim dan mitra juga akan melaksanakan workshop pengemasan produk untuk Usaha kecil. Workshop ini bertujuan untuk meningkatkan pemahaman dan keterampilan mitra dalam pengemasan produk yang lebih menarik. Packaging berperan penting untuk menghasilkan produk yang menarik sehingga diharapkan mampu meningkatkan pendapatan dan juga sebagai media promosi melalui pelabelan yang ada pada produk. Materi pelatihan meliputi 1) fungsi kemasan, 2) syarat kemasan, 3) teknologi dan cara pengemasan.
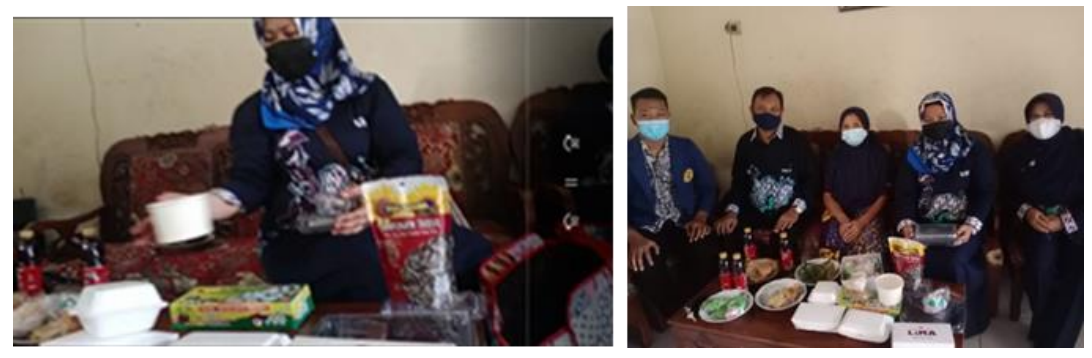

Gambar 7.

Pelatihan Pemasaran Online dan Workshop Pengemasan Produk bagi Usaha Kecil

4. Pelatihan pembukuan sederhana dan pengelolaan keuangan untuk UMKM. Pelatihan pembukuan dilakukan guna meningkatkan keterampilan mitra dalam pengelolaan keuangan. Mitra dalam hal ini adalah ibu bekerja, sehingga perlu untuk diberikan pelatihan bagaimana membuat pembukuan sederhana untuk memisahkan antara keuangan keluarga dan keuangan usaha. Penyusunan perencanaan keuangan, analisis BEP, pengelolaan keuangan dan pembukuan efektif dilakukan dengan pendekatan pendampingan dan tutorial (Zubaidah, 2018).

5. Pelatihan Penentuan Harga Jual Produk. Harga pokok produksi merupakan elemen penting untuk menentukan harga jual produk. Harga pokok produksi pada dasarnya menunjukkan harga pokok produk (barang dan jasa) yang diproduksi dalam suatu periode akuntansi tertentu. Hal ini berarti bahwa harga pokok produksi merupakan bagian dari harga pokok, 
yaitu harga pokok dari produk yang terjual dalam satu periode akuntansi (Purnamawati, dkk, 2017). Dari harga pokok tersebut mitra dapat menentukan harga jual produk yang kompetitif. Materi dalam pelatihan harga jual produk ini mencakup (1) Identifikasi Biaya Produksi, (2) Penyusunan Harga Pokok Produksi, (3) Penentuan Harga Jual Produk.

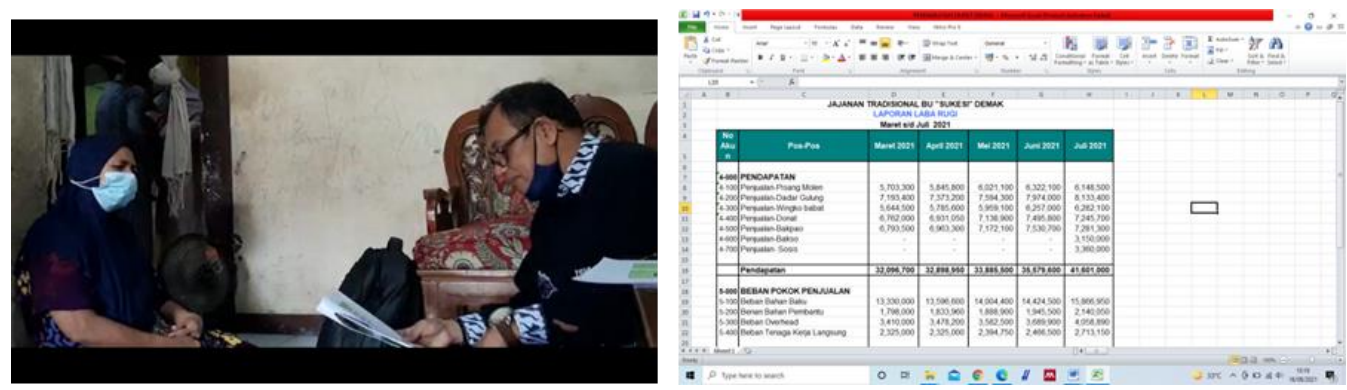

Gambar 8.

Pelatihan Pembukuan Sederhana dan Penentuan Harga Jual Produk

6. Evaluasi Kinerja. Pada tahap ini akan dilakukan evaluasi kinerja dari program-program yang telah dilaksanakan berdasar indikator dan luaran yang direncanakan. Evaluasi kinerja terdiri dari aspek produksi, pemasaran dan keuangan.

\section{PEMBAHASAN}

Adapun dampak ekonomi dan social yang dirasakan oleh mitra setelah pelaksanaan beberapa kegiatan PKM meliputi:

1. Peningkatan omzet

Tabel 5. Peningkatan Omzet

\begin{tabular}{|c|c|c|c|c|c|}
\hline Pos-Pos & Maret 2021 & April 2021 & Mei 2021 & Juni 2021 & Juli 2021 \\
\hline \multicolumn{6}{|l|}{ PENDAPATAN } \\
\hline Penjualan-Pisang Molen & $5,703,300$ & $5,845,800$ & $6,021,100$ & $6,322,100$ & $6,148,500$ \\
\hline Penjualan-Dadar Gulung & $7,193,400$ & $7,373,200$ & $7,594,300$ & $7,974,000$ & $8,133,400$ \\
\hline Penjualan-Wingko babat & $5,644,500$ & $5,785,600$ & $5,959,100$ & $6,257,000$ & $6,282,100$ \\
\hline Penjualan-Donat & $6,762,000$ & $6,931,050$ & $7,138,900$ & $7,495,800$ & $7,245,700$ \\
\hline Penjualan-Bakpao & $6,793,500$ & $6,963,300$ & $7,172,100$ & $7,530,700$ & $7,281,300$ \\
\hline Penjualan-Bakso & - & - & - & - & $3,150,000$ \\
\hline Penjualan- Sosis & - & - & - & - & $3,360,000$ \\
\hline Pendapatan & $32,096,700$ & $32,898,950$ & $\mathbf{3 3 , 8 8 5 , 5 0 0}$ & $35,579,600$ & $41,601,000$ \\
\hline
\end{tabular}

Dari tabel di atas terlihat bahwa terjadi peningkatan omzet dari mitra pada bulan Juli 2021 sebesar 17\%. Peningkatan omzet tersebut terjadi karena mitra membuat diversifikasi produk berupa bakso dan sosis. 


\section{Peningkatan Keterampilan Penggunaan Mesin}

Dengan fasilitasi mesin yang diberikan, khusunya mesin pengaduk adonan mitra telah mampu menggunakan mesin. Sehingga dalam pembuatan adonan tidak lagi dilakukan secara manual tetapi menggunakan mesin. Hal tersebut juga memberikan dampak positif pad kesehatan mitra terutama pada kuku jari mitra yang sebelumnya ditumbuhi jamur karena sisa adonan, sekarang telah mulai berkurang.

3. Peningkatan Pemahaman dan Keterampilan Mitra dalam Melakukan Pembukuan Sederhana dan memisahkan keuangan keluarga dan bisnis

Sebelum pelaksanaan PKM, mitra tidak memiliki pembukuan dan pencatatan keuangan sehingga menyebabkan keuntungan atau kerugian tidak dapat terdeteksi dengan baik. Keuangan keluarga dan bisnis bercampur jadi satu. Mitra belum mampu menentukan harga pokok produksi produk diversifikasinya sebagai dasar penentuan harga jual. Setelah pelaksanaan pengabdian mitra memiliki pembukuan sederhana dan mampu menentukan harga jual untuk produk barunya yaitu sosis dan bakso. Penyampaian informasi dan pembimbingan personal kepada pelaku UMKM semakin meningkatkan motivasi dalam mengaplikasikan akuntansi sederhana dalam menjalankan usahanya (Hapsari, Putri, Nahdiatul, 2017; Hadiwijaya, Febrianty, Darmawi, 2020). 4. Perluasan Jangkauan Pemasaran

Sebelum pelaksanaan PKM, mitra hanya melayani satu pasar yaitu pasar Bintoro Demak. Setelah pelaksanaan PKM, jangkauan pasar mitra lebih luas yaitu selain di pasar Bintoro mitra juga melayani pasar Buyaran Demak. Hal ini disebabkan karena mitra mampu memproduksi lebih banyak dan mitra memiliki diversifikasi produk yang baru untuk memperluas pasar. Analisis efektifitas strategi pemasaran menunjukkan adanya peningkatan total penjualan dari tahun ke tahun dan dijadikan dasar efektifitas strategi pemasaran dalam persaingan usaha (Wibowo, 2015).

\section{KESIMPULAN}

Manfaat yang diperoleh mitra dari program pengabdian kepada masyarakat ini meliputi: (1) Peningkatan omzet, (2) Peningkatan Keterampilan Penggunaan Mesin, (3) Peningkatan Pemahaman dan Keterampilan Mitra dalam Melakukan Pembukuan Sederhana dan memisahkan keuangan keluarga dan bisnis dan (4) Perluasan Jangkauan Pemasaran. Adapun peran aktif mitra adalah sebagai berikut: (1) Bersama Tim menentukan permasalahan yang disepakati, (2) Sebagai penyedia tempat untuk seluruh kegiatan pelatihan dan workshop, (3) Sebagai penyedia bahan workshop variasi produk, (4) Berperan aktif dalam setiap kegiatan pelatihan maupun workshop. Saran yang diberikan untuk kemajuan usaha mitra adalah dengan fasilitasi alat produksi yang diberikan, mitra dapat terus berinovasi menciptakan produk-produk diversifikasi untuk mengatasi kebosanan selera pasar. Selain itu mitra diharapkan tetap konsisten dan continue menerapkan pembukuan sederhana pada usaha yang dijalankan. Ucapan Terimakasih disampaikan kepada LPPM Universitas Semarang dan DRPM RISTEK - DIKTI atas terselenggaranya program pengabdian kepada masyarakat. 


\section{DAFTAR PUSTAKA}

Assauri, S. 2013. Manajemen Pemasaran. Rajawali Pers.

Agustono; Utami, Bekti Wahyu; Setowati, Nuning. 2017. Diversifikasi Produk sebagai Upaya Strategi Pemasaran Produk Olahan Jagung (Kasus UKM Marning Desa Sidomukti Kecamatan Jenawi Karanganyar). Seminar Nasional 6th UNS SME's SUMMIT \& Awards 2017, Peningkatan Daya Saing UMKM Berbasis Ekonomi Kreatif dalam Era Masyarakat Ekonomi ASEAN.

Boko, M. 2006. Penerapan Cara Produksi Pangan yang Baik dan Penggunaan Teknologi Pengemasan untuk Meningkatkan Mutu Produk Makanan di Wilayah Ratu Boko, Yogyakarta: Universitas Negeri Yogyakarta.

Ebert, R. J., \& Griffin, R. W. 2007. "Bisnis", Alih Bahasa Rd. Soemarnagara. Erlangga.

Hadiwijaya, Hendra; Febrianty; Darmawi. 2020. Pendampingan Manajemen Usaha dan Permodalan pada UMKM Batu Bata. CARADDE: Jurnal Pengabdian kepada Masyarakat, Vol.2, No.2, 353-359, DOI: https://doi.org/10.31960/caradde.v2i2.396

Hapsari, Denny Putri; Andari; Nahdiatul, A. H. 2017. Model Pembukuan Sederhana Bagi Usaha Mikro di Kecamatan Kramatwatu Kabupaten Serang. Jurnal Akuntansi, 4(2), 36-47.

Nurita, R.F. 2016. Upaya Pemberdayaan Ibu Rumah Tangga di Desa Kalirejo Lawang dengan Tujuan Memotivasi Kewirausahaan Mandiri (Pelatihan Pembuatan Penganan Cokelat dengan Varian Inovasi Isi, Rasa dan Pengemasan), Jurnal ABDIMAS Unmer Malang, Vol 1. Nomor 2.

Purnamawati, I.G.A; Yuniarta, G.A; Diatmika, I.P.G. 2017. Pelatihan dan Pendampingan Penyusunan Harga Pokok Penjualan Berdasarkan Metode Akuntansi pada Usaha Tenun. Seminar Nasional Pengabdian kepada Masyarakat

Yushita, A.N. 2014 Pelatihan Pencatatan Keuangan untuk Usaha Kecil, Universitas Negeri Yogyakarta.

Zubaidah, S. 2018. Pendampingan Manajemen Usaha Pada UKM IT (Information Technologi) Di Malang. Jurnal Studi Kasus Inovasi Ekonomi, 02(01), 29-34. https://doi.org/https://doi.org/10.22219/skie.v2i01.5496.g5252 